\title{
Health risk related to whole-body vibration in agricultural tractor: ballast and displacement speed
}

\author{
Insalubridade vibracional em trator agrícola: lastragem e velocidade de \\ deslocamento
}

\begin{abstract}
Jefferson SANDI ${ }^{1}$; Carlos Renato Guedes RAMOS ${ }^{2}$; Fernanda Scaranello DRUDI ${ }^{3}$; Murilo Battistuzzi MARTINS ${ }^{3}$; Kléber Pereira LANÇAS ${ }^{4}$

${ }^{1}$ Autor para correspondência, Mestre em agronomia (Energia na Agricultura); Faculdade de Ciências Agronômicas/Botucatu SP; Departamento de Engenharia Rural; Rua José Barbosa de Barros, no 1780; jffsandi@gmail.com

${ }^{2}$ Doutor em Agronomia (Energia na Agricultura); TMA - Campus de Tomé-Açu, PA; carlosrgramos@outlook.com

${ }^{3}$ Mestre em agronomia (Energia na Agricultura); Faculdade de Ciências Agronômicas/Botucatu - SP; fernandadrudi@gmail.com; mbm_martins@hotmail.com

${ }^{4}$ Professor Titular Departamento de Engenharia Rural; Faculdade de Ciências Agronômicas/Botucatu - SP; kplancas@fca.unesp.br
\end{abstract}

Recebido em: 03-10-2017; Aceito em: 06-12-2017

\begin{abstract}
Mechanical vibration can lead to health problems in workers during the performance of their professional activities. The objective of this study was to evaluate the vibration incident on the whole body of the agricultural tractor operator in a standard track of vibration tests under different ballast conditions and displacement speeds. A $4 \times 2$ AFWD agricultural tractor with $92 \mathrm{~kW}$ engine power was tested in four ballast conditions: total ballast (70 kN); solid ballast only (54 kN); liquid ballast only (54 kN); and without any ballast (48 kN), at four working speeds: $1.19 \mathrm{~m} \mathrm{~s}^{-1}$; $1.47 \mathrm{~m} \mathrm{~s}^{-1} ; 1.75 \mathrm{~m} \mathrm{~s}^{-1}$ and $2.08 \mathrm{~m} \mathrm{~s}^{-1}$. The values regarding axle accelerations, the sum of axes for mean accelerations, and the vibration dose value were evaluated by analysis of variance and separation of means (Tukey, $\mathrm{p}<0.05$ ), in addition to principal components analysis (PCA). Speed was the most influential factor in the vibration generated. The lowest values of mean acceleration and vibration dose value were found in the combination of the lowest speeds with the highest weight of the tractor, while the highest values occurred in the combination of higher speeds with lower weight and liquid ballast. The accelerations obtained on the $y$ axis were more determinant in data behavior than those found in the $x$ and $z$ axes.
\end{abstract}

Additional keywords: agricultural machinery; comfort; ergonomics; occupational injuries.

\section{Resumo}

A vibração mecânica pode ser causa de problemas de saúde em trabalhadores durante o desempenho de suas atividades profissionais. Objetivou-se avaliar a vibração incidente sobre o corpo inteiro do operador de trator agrícola em pista normatizada de ensaios de vibração, em diferentes condições de lastragens e velocidades de deslocamento. Utilizou-se um trator agrícola 4x2 TDA com $92 \mathrm{~kW}$ de potência no motor, ensaiado em quatro condições de lastragem: totalmente lastrado $(70 \mathrm{kN})$, empregando somente lastro sólido (54 kN), somente lastro líquido $(54 \mathrm{kN})$ e sem qualquer tipo de lastro (48 kN), em quatro velocidades de trabalho: $1,19 \mathrm{~m} \mathrm{~s}^{-1} ; 1,47 \mathrm{~m} \mathrm{~s}^{-1}$; $1,75 \mathrm{~m} \mathrm{~s}^{-1}$ e $2,08 \mathrm{~m} \mathrm{~s}^{-1}$. Avaliaram-se os valores de acelerações por eixo, valores de soma dos eixos para acelerações médias e valor da dose de vibração por meio da análise de variância e separação de médias (Tukey, $\mathrm{p}<0,05)$ e da análise de componentes principais. A velocidade foi o fator mais influente na vibração gerada. Os menores valores de aceleração média e valor dose de vibração foram encontrados na combinação das menores velocidades com o maior peso do trator, enquanto os maiores valores ocorreram na combinação das maiores velocidades com o menor peso e lastragem líquida. As acelerações obtidas no eixo y foram mais determinantes no comportamento dos dados que as encontradas nos eixos x e $z$.

Palavras-chave adicionais: conforto; ergonomia; lesões ocupacionais; máquinas agrícolas.

\section{Introduction}

According to Annex 8 of the Regulatory Standard 15 (NR-15) (Brasil, 2014), vibration characterizes health risk at work and determines an additional remuneration of $20 \%$ of the minimum wage when the acceleration values resulting from normalized exposure (aren) and the representative vibration dose value (rVDV) are above $1.1 \mathrm{~m} \mathrm{~s}^{-2}$ and $21.0 \mathrm{~m} \mathrm{~s}^{-1,75}$, respectively, being up to the employer to verify the evaluation of the two parameters

This is because mechanical vibrations, caused both by the machine's operation and by the roughness of the displacement surface, become problematic when the frequency of parts of the human body (for example, the trunk vibrates at a frequency of 4 to $8 \mathrm{~Hz}$ ) 
gets close to the frequency of the tractor $(1 \mathrm{to} 7 \mathrm{~Hz})$, causing the resonance effect (Zehsaz et al., 2011). According to Silva (2011), over time, the seat was the agricultural tractor's component that contributed more significantly to the behavioral change by providing better body stability and vibration attenuation; however, this has generated ergonomic problems for the arrangement of the commands. Suspension systems can help reduce the vibration levels that reach the operating room, but according to Nguyen \& Inaba (2011), most medium and small tractors do not have suspension systems, with a view to reduce their cost and maintenance complexity. In addition, in some countries, due to economic reasons, tractors without suspensions in the cabin and in the seat are in greater demand, causing the manufacturers to provide only the cabin insulation from dust and water in their products (Zehsaz et al., 2011).

Koley et al. (2010) studied the relationship between operator age and operating time (years) in the performance of tractor operation, obtaining a correlation between the two factors, where operators over 31 years of age performing the activity for more than 11 years were more likely to feel back pain; the authors suggest that proper exercise and diets can help combat and prevent this problem.

In Brazil, the Regulatory Standards (NRs) concerning occupational safety and medicine deal with aspects related to health risk in labor activities. NR-15 establishes tolerance limits for each activity according to the concentration or intensity of exposure of the worker to the harmful agent. However, this standard does not refer to limits of exposure to vibration, which leads to the adoption of international standards for testing, among them ISO 2631 and 2002/44/EC of the European Community, which stipulate levels of action and limits of human exposure to whole-body vibrations (Santos, 2014).

Currently, there is the possibility of using standardized tracks described in standards from standardization bodies and entities for the performance of vibration tests, such as ISO 5008. It establishes the characteristics of two test tracks, of 35 and $100 \mathrm{~m}$, each consisting of two parallel strips with wood, metal or concrete steps of different heights (rendering them asymmetrical), where the tractor tires pass, in addition to the manner of conducting the test, such as tractor conditions, number of repetitions, working speeds for each track (4.0 to $7 \mathrm{~km} \mathrm{~h}^{-1}$ for the 35-meter track, and 10 to $14 \mathrm{~km} \mathrm{~h}^{-1}$ for the 100 -meter track), the method for fixing the equipment, and the parameters to be measured.

Therefore, the objective was to evaluate the vibration incident on the whole body of the agricultural tractor operator in a standardized track for vibration tests under different ballast conditions and displacement speeds.

\section{Material and methods}

Data collection was carried out on a track for vibration tests in agricultural tractors, built in wood according to the standard ISO 5008 (2002) (Figure 1), and located at the geographical coordinates: $22^{\circ} 51^{\prime} \mathrm{S}$ and $48^{\circ} 25^{\prime} \mathrm{W}$, at an altitude of 770 meters.

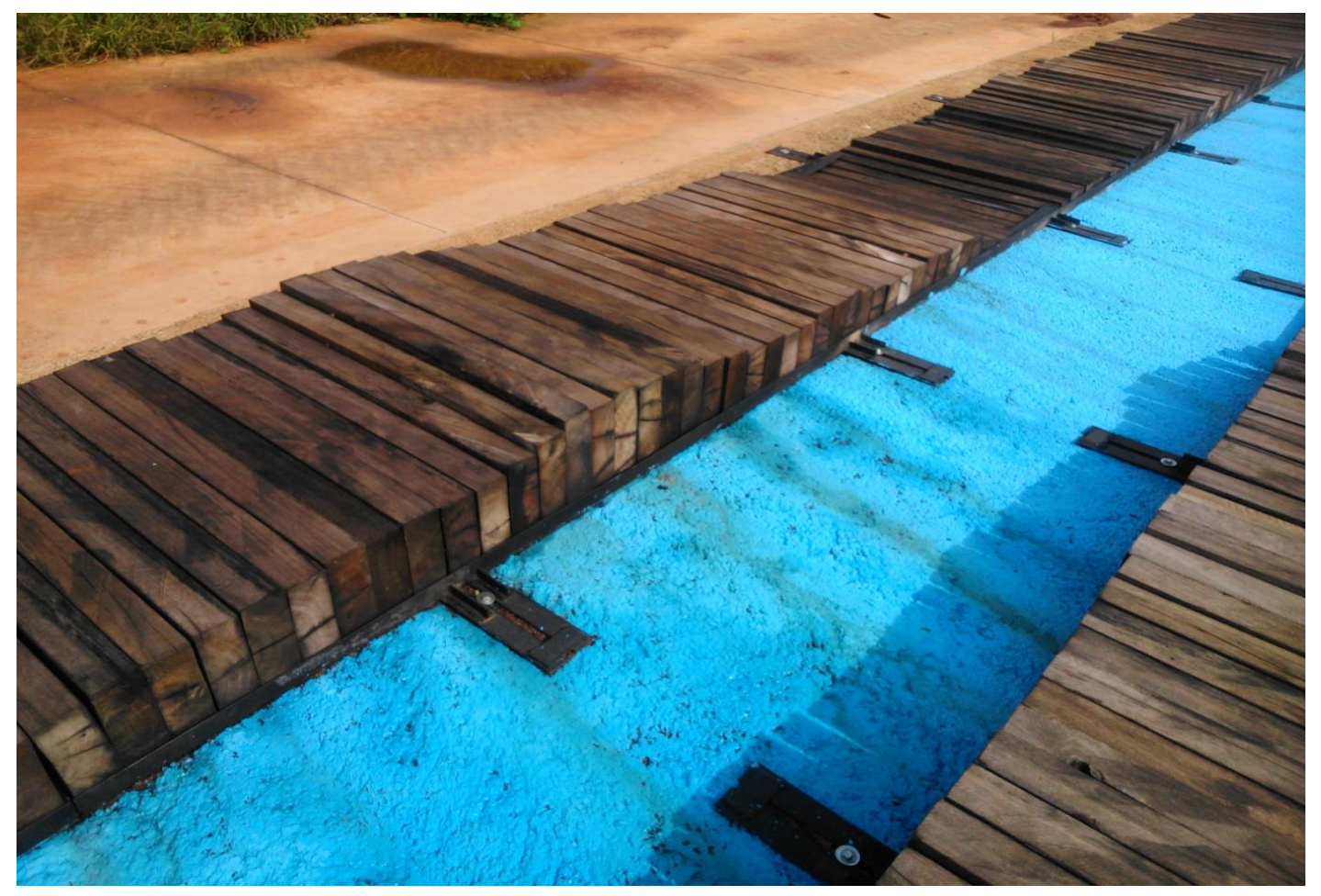

Figure 1 - Vibration track used for testing. 
A 4x2 AFWD agricultural tractor with $92 \mathrm{~kW}$ engine power was used, tested with different weights obtained from the alteration of the quantity and types of ballast, and using a set of TM-95 diagonal tires (14.924 - front; and 23.1-30 - rear). The tractor seat is type FA 418/631, manufactured by Grammer AG of Brazil

To obtain the data, the HVM 100 accelerator was used in conjunction with the three-axis (axes $\mathrm{x}, \mathrm{y}$, and z) accelerometer SEN027 - Seat Pad, both manufactured by Larson Davis; the software Blaze 6.1.1 was used for data collection and transfer. The HMV100 was set to operate in the whole-body mode, ICP accelerometer, $2.8 \mathrm{~m} \mathrm{~s}^{-2}$ exposure reference, without integration, frequency weighting, multiplicative factors of 1.4 (for the $x$ and $y$ axes) and 1 ( $z$ axis), and data acquisition rate of $1 \mathrm{~Hz}$. The calibration of the equipment was done prior to the tests.

The whole-body measurement system was attached to the operator's seat according to $\mathrm{NHO} 09$ (Fundacentro, 2013), using the three-axis accelerometer (flexible disc, with a central accelerometer) to measure the vibration applied to all the human body, according to the three axes. The Cartesian coordinates used in the fixation of the accelerometer to the seat were: $x$ axis - front/rear; y axis - right/left; $z$ axis - up/down. To prevent the disc from moving, it was attached to the seat by means of adhesive tape (Figure 2).

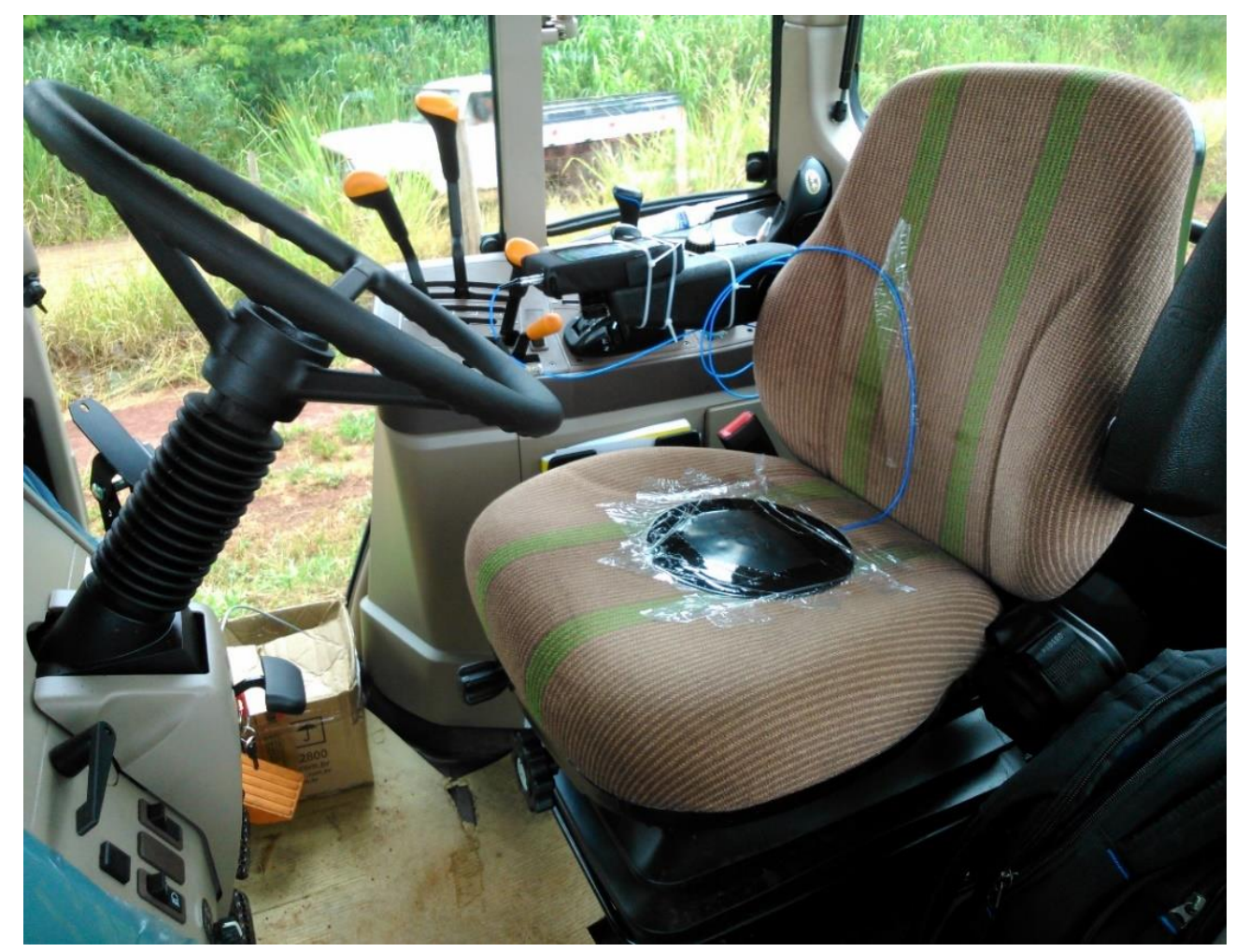

Figure 2 - Accelerometer attachment to operator's seat.

The engine rotation speed was determined using a digital tachometer, model DT6234B, measuring the rotation speed of the engine crankshaft. All data collection was performed with the engine at 2,300 rpm on the crankshaft. Auxiliary front wheel drive remained on during all data collection. The seat was set to the operator weight $(61 \mathrm{~kg})$, remaining in the same condition throughout the test.

The tractor was tested with four ballast conditions, which resulted in three different weights: $70 \mathrm{kN}$ when fully ballasted using a combination of solid and liquid ballasts (B1), $54 \mathrm{kN}$ when using only solid ballast (B2) or only liquid ballast (B3), and $48 \mathrm{kN}$ due to the absence of any additional ballast (B4). In all situations, the same weight distribution was adopted (35\% on the front axle and $65 \%$ on the rear axle).

Four working speeds were adopted on the test track: $1.19 \mathrm{~m} \mathrm{~s}^{-1}(\mathrm{~S} 1) ; 1.47 \mathrm{~m} \mathrm{~s}^{-1}(\mathrm{~S} 2) ; 1.75 \mathrm{~m} \mathrm{~s}^{-1}$ (S3); and $2.08 \mathrm{~m} \mathrm{~s}^{-1}$ (S4). The tires were inflated with internal pressures of 82.73 and $110.31 \mathrm{kPa}$ in the front and rear wheels, respectively.

The experimental design was randomized blocks in a factorial scheme, with five replications. The parameters evaluated during the tractor displacement on the vibration track were: the axle acceleration values, the sum of the axes for mean accelerations, and the vibration dose value (VDV), based on the criteria for judgment and decision making presented in the Occupational Hygiene Standard 09 - NHO 09 (Fundacentro, 2013).

For the data obtained from the three axes (sense of mechanical vibration), principal component analysis was performed in the software Blaze 6.1.1 to evaluate their correlation. For the unit data obtained 
by the same software (considered as sum), tests of normality and homogeneity were conducted. For the data that followed normal distribution, analysis of variance was applied, being complemented by the Tukey test; otherwise, the Kruskal-Wallis-Runs test was applied. Statistical significance was considered when $p<0.05$. All analyses were performed using the softwares Minitab ${ }^{\circledR}$ 16.2.4.4 and $\mathrm{SAS}^{\circledR}{ }^{\circledR}$ 9.3.

\section{Results and discussion}

The lowest values of mean acceleration were obtained from the combination of the lowest working speed (S1) with the maximum ballast (B1), while the highest values of mean acceleration occurred in the speed S4 in combination with the ballasts B3 and B4 (Table 1).

Table 1 - Values of mean acceleration sum $\left(\mathrm{m} \mathrm{s}^{-2}\right)$ for different ballasts and displacement speeds.

\begin{tabular}{lcccc}
\hline \multirow{2}{*}{ Ballast } & \multicolumn{4}{c}{ Speed } \\
\cline { 2 - 5 } & $\mathrm{S} 1-1.19 \mathrm{~m} \mathrm{~s}^{-1}$ & $\mathrm{~S} 2-1.47 \mathrm{~m} \mathrm{~s}^{-1}$ & $\mathrm{~S} 3-1.75 \mathrm{~m} \mathrm{~s}^{-1}$ & $\mathrm{~S} 4-2.08 \mathrm{~m} \mathrm{~s}^{-1}$ \\
\hline B1 - 70 kN using solid and liquid & $2.58 \mathrm{Cd}$ & $3.14 \mathrm{Dc}$ & $3.79 \mathrm{Db}$ & $4.90 \mathrm{Ca}$ \\
B2 - 54 kN only solid ballast & $2.85 \mathrm{Bd}$ & $3.37 \mathrm{Cc}$ & $3.97 \mathrm{Cb}$ & $5.34 \mathrm{Ba}$ \\
B3 - 54 kN only liquid ballast & $3.05 \mathrm{Ad}$ & $3.67 \mathrm{Ac}$ & $4.60 \mathrm{Ab}$ & $5.55 \mathrm{Aa}$ \\
B4 - 48 kN absence of any additional & $3.00 \mathrm{Ad}$ & $3.52 \mathrm{Bc}$ & $4.34 \mathrm{Bb}$ & $5.57 \mathrm{Aa}$ \\
\hline \multicolumn{5}{c}{$\mathrm{F} \mathrm{Test}$} \\
\hline Ballast & \multicolumn{4}{c}{$42.95^{\star *}$} \\
Speed & \multicolumn{4}{c}{$665.39^{* *}$} \\
Ballast x Speed & \multicolumn{4}{c}{$1.43^{\star *}$} \\
\hline CV (\%) & \multicolumn{4}{c}{1.48} \\
\hline
\end{tabular}

Means followed by the same capital letter do not differ from each other in the column and the same lowercase letter does not differ from each other in the row by the Tukey test $(p>0.05)$. ns: not significant by the $F$ test at the $5 \%$ probability level. * Significant by $\mathrm{F}$ test at $5 \%$ probability level. ${ }^{* *}$ Significant by $\mathrm{F}$ test at $1 \%$ probability level.

The largest weight in combination with the lowest working speed provides lower levels of inertial energy and greater stability to the tractor during its displacement. This allows mainly the tires to better adapt to the irregularities of the surface, attenuating the mechanical vibrations generated by the movement of the machine, diminishing the importance of this source of vibration in relation to the others, which results in lower levels of incidence on the operator. This is corroborated by the higher speed of work generating the highest values of mean accelerations due to the higher inertial energy and faster movements caused in this situation. Franchini (2007) has obtained results that show that in the range of 0 to $15 \mathrm{~Hz}$, vibration was amplified due to the use of all-metal ballast, which also occurred in the range of 0 to $19 \mathrm{~Hz}$ due to the use of part-metal ballast, and in the range of 71 to $76 \mathrm{~Hz}$ with the use of all-liquid ballast. The transmissibility values in the analysis of 1 to $80 \mathrm{~Hz}$ corresponded to 59,74 , and $88 \%$, respectively, for the all-metal ballast, partmetal ballast, and all-liquid ballast.

The high mean acceleration values obtained in this test on a 35-m vibration track are due to the characteristics of the track, which seeks to simulate a condition of great irregularity in the work area, such as those found in soils recently worked with plows and subsoilers, or when there are obstacles in the middle of the field, such as siltation channels, beds, chameleons, stones, branches, and stumps.

Table 2 shows the vibration dose values (VDV) results obtained for the different ballasts and velocities during the vibration test on a 35-meter track, with the lowest vibration dose values occurring in the speed $\mathrm{S} 1$ and in the treatment with maximum ballast at speed S2, while the highest values were found in the speed S4.

Table 2 - Vibration dose values (VDV; $\mathrm{m} \mathrm{s}^{-1,75}$ ) for different ballasts and displacement speeds.

\begin{tabular}{|c|c|c|c|c|}
\hline \multirow[b]{2}{*}{ Ballast } & \multicolumn{4}{|c|}{ Speed } \\
\hline & $\mathrm{S} 1-1.19 \mathrm{~m} \mathrm{~s}^{-1}$ & $\mathrm{~S} 2-1.44 \mathrm{~m} \mathrm{~s}^{-1}$ & $\mathrm{~S} 3-1.75 \mathrm{~m} \mathrm{~s}^{-1}$ & $\mathrm{~S} 4-2.08 \mathrm{~m} \mathrm{~s}^{-1}$ \\
\hline B1 - $70 \mathrm{kN}$ - using solid and liquid & $7.48 \mathrm{Ac}$ & $8.50 \mathrm{Bc}$ & $11.18 \mathrm{Ab}$ & $4.90 \mathrm{Ca}$ \\
\hline B2 - $54 \mathrm{kN}$ - only solid ballast & $7.88 \mathrm{Ac}$ & $9.13 \mathrm{ABb}$ & $10.06 \mathrm{Bb}$ & $5.34 \mathrm{Ba}$ \\
\hline B3 - $54 \mathrm{kN}$ - only liquid ballast & $8.45 \mathrm{Ad}$ & $9.81 \mathrm{Ac}$ & $12.00 \mathrm{Ab}$ & $5.55 \mathrm{Aa}$ \\
\hline \multirow[t]{2}{*}{ B4 - $48 \mathrm{kN}$ - absence of any additional } & $8.31 \mathrm{Ad}$ & $9.34 \mathrm{ABC}$ & $10.98 \mathrm{ABb}$ & $5.57 \mathrm{Aa}$ \\
\hline & \multicolumn{4}{|c|}{$\mathrm{F}$ test } \\
\hline Ballast & \multirow{2}{*}{\multicolumn{4}{|c|}{$\begin{array}{c}1.24^{\star *} \\
57.57^{\star *}\end{array}$}} \\
\hline Speed & & & & \\
\hline Ballast * Speed & \multicolumn{4}{|c|}{$0.46^{\star *}$} \\
\hline CV (\%) & \multicolumn{4}{|c|}{4.65} \\
\hline
\end{tabular}

Means followed by the same capital letter do not differ from each other in the column and the same lowercase letter does not differ from each other in the row by the Tukey test $(p>0.05)$. ns: not significant by the $\mathrm{F}$ test at the $5 \%$ probability level. * Significant by $\mathrm{F}$ test at $5 \%$ probability level. ${ }^{* *}$ Significant by $\mathrm{F}$ test at $1 \%$ probability level. 
VDV represents the cumulative vibration exposure in a working day, being more indicated for assessing the effect of vibration on the human body in journeys longer than 8 hours, since it represents more adequately the bumps and shocks that occur during the operation (Scarlett et al., 2007). Occupational exposure situations above the action level imply the mandatory adoption of preventive measures, while occupational exposure scenarios above the exposure limit imply the mandatory adoption of corrective measures. The values found were due to the purpose and the constructive form of the 35-m vibration track, which seeks to simulate a bumpy surface that the tractors can normally encounter in the field during different operations, especially those regarding the preparation and cleaning of the area, or those carried out on very irregular terrains with natural obstacles such as stones or holes.

According to Balbinot (2001), when the value of $8.5 \mathrm{~m} \mathrm{~s}^{-1.75}$ is exceeded, there is the possibility of general discomfort, since this evaluation parameter indicates the severity of exposure to vibration; however, there is no consensus in the scientific community about the precise relationship between VDV and the risk of injury to the human body. During the performance of field activities, VDVs around $15 \mathrm{~m} \mathrm{~s}^{-1.75}$ can usually occur on very bumpy surfaces, causing severe discomfort, pain, and injury. In turn, Metha et al. (2000), found variation in the vibration dose values for eight hours of work during the displacement of a tractor with plow and harrow in transport mode at the speeds of 1.64, 1.79, and $0.51 \mathrm{~m} \mathrm{~s}^{-1}$, on tarmacadam asphalt, farm road, and in the field, respectively; at the speeds of $0.69,1.54$, and $0.51 \mathrm{~m} \mathrm{~s}^{-1}$.

As can be seen in Table 3, the mean acceleration and VDV of the three axes ( $a_{x}, a_{y}$, and $\left.a_{z}\right)$ contributed almost equally to define the direction and behavior of the first component, while for the second component, the $y$-axis values determined the direction and behavior. This implies that the acceleration values on the $y$ axis were more responsible for the data distribution behavior than the other accelerations.

Table 3 - Main components for average mean acceleration and vibration dose value (VDV).

\begin{tabular}{|c|c|c|}
\hline Axis & \multicolumn{2}{|c|}{ Mean aceleration } \\
\hline AXIS & First component & Second component \\
\hline $\mathrm{X}$ & 0.601 & -0.376 \\
\hline $\mathrm{Y}$ & 0.526 & 0.851 \\
\hline Z & 0.602 & -0.368 \\
\hline & \multicolumn{2}{|c|}{ Vibration dose value } \\
\hline Axis & First component & Second component \\
\hline $\mathrm{X}$ & 0.606 & -0.322 \\
\hline $\mathrm{Y}$ & 0.527 & 0.848 \\
\hline Z & 0.597 & -0.422 \\
\hline
\end{tabular}

This result can be attributed mainly to the asymmetry between the stretches of the track, which reproduces a very common situation on dirt roads and in work situations in the field, where the wheels on each side of the tractor undergo different obstacles and irregularities of the terrain. This agrees with the study by Cunha et al. (2009), where acceleration values in the tractor displacement direction (y axis) were higher than those found in the other axes ( $x$ and $z$ ), exceeding the tolerable values presented in the standard ISO 2631-1 (1997) for plowing and harrowing activities; in some cases, non-tolerable values were reached.

Scarlett et al. (2007) attributed the highest values of accelerations in the $y$ axis to the lower capacity of the agricultural tractor seat to attenuate vibrations in this direction, with the intensity of the vibrations being dependent on the type of operation performed. From Figures $3 \mathrm{~A}$ and $3 \mathrm{~B}$, it can be seen that the values of $x$ and $z$ presented a very similar behavior for mean acceleration and VDV, while those related to the $y$ axis differed in direction from the other axes.

According to Scarlett et al. (2007), accelerations occurring on the transverse axis (y) are dominant during most of the performance of agricultural tractor operations, except for displacement and transport activities, when the accelerations occurring on the $x$ axis become more determinant. This is corroborated by Marsilli et al. (2002), who present great reductions in the vibrations incident on the operator when systems that attenuate the vibration in the $x$ and $y$ axes are used in activities that provide low frequency of oscillation.

Figures 4 and 5 show that speed had a more significant influence than ballast to determine the differences between the treatments by forming four distinct groups of data (one for each speed tested, except for a small overlap between speeds S1 and S2), both for mean acceleration and for VDV. In Figures 6 and 7, for both the mean acceleration data and the VDV data, it is possible to establish a curve for each ballast, but since they overlap, they do not allow the separation of the data into different groups.

This demonstrates that speed plays a fundamental role in the vibration levels that affect the operator due to the increase in the magnitude of the machine movements with the increase of the working speed. Lines (1987) concluded that the vibrational energy is dissipated by the tires, being directly proportional to the increase of the working speed. 

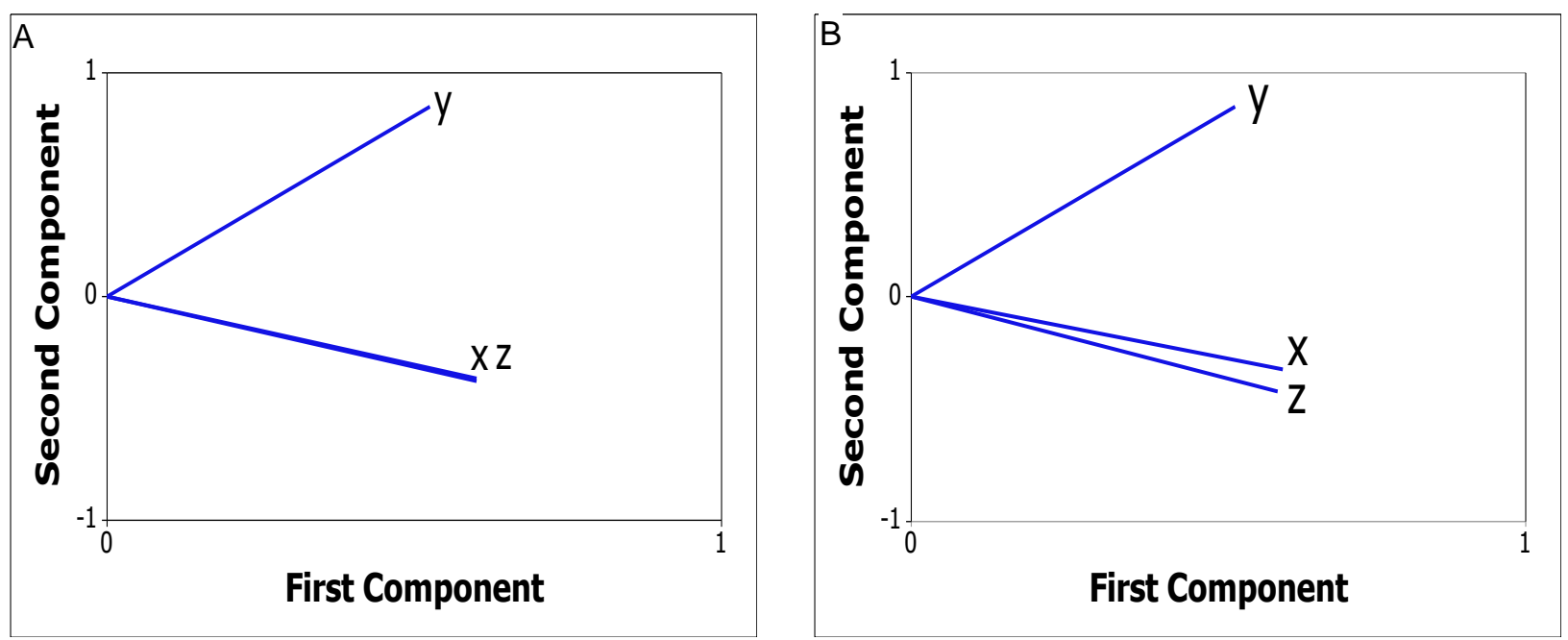

Figure 3 - A) Analysis of principal components of the resulting mean acceleration for each axis (ax; $a_{y}$ and $\left.a_{z}\right)$. B) Analysis of main components of the vibration dose value for each axis ( $a_{x} ; a_{y}$ and $\left.a_{z}\right)$.

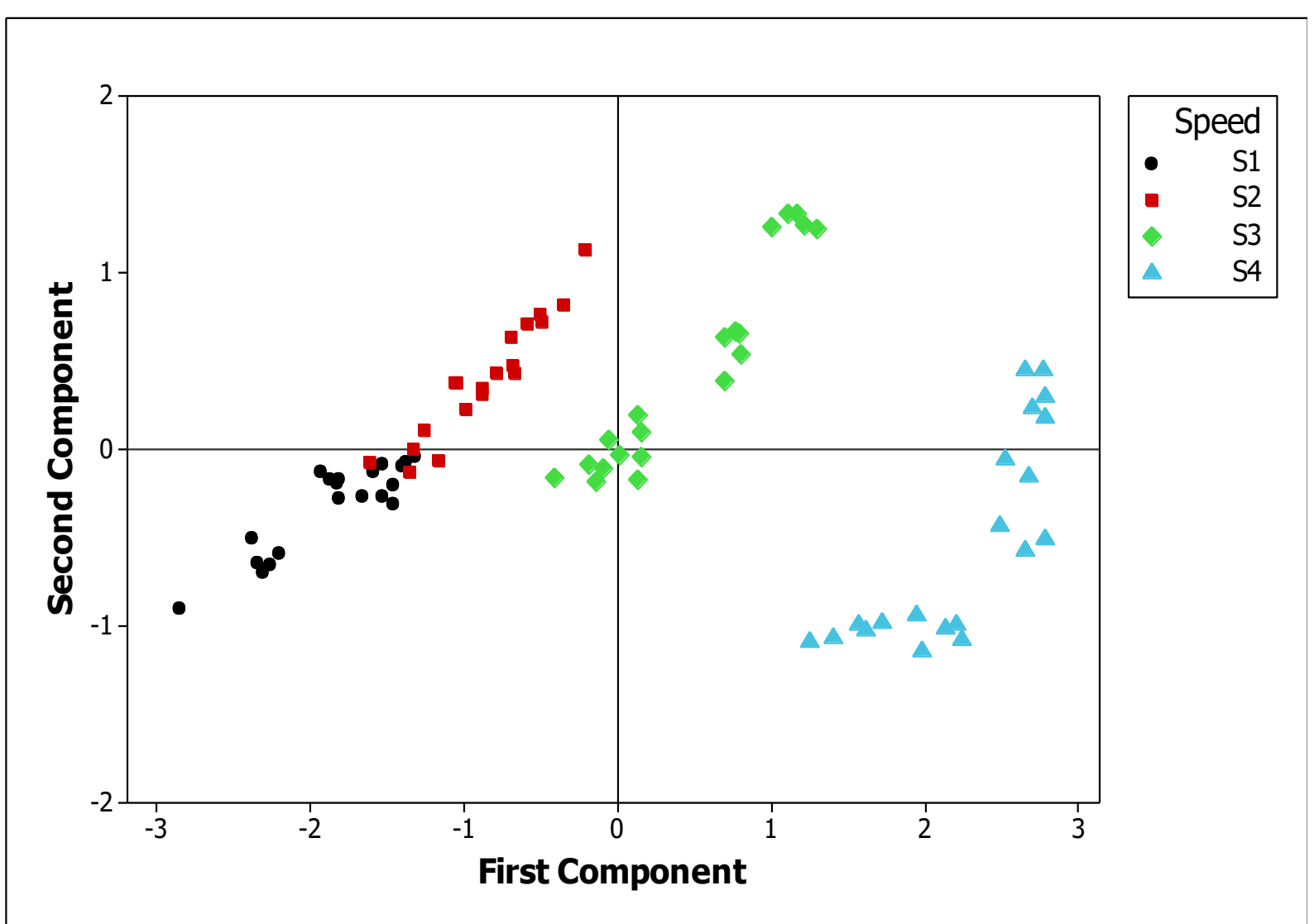

Figure 4 - Dispersion of the mean acceleration values for different displacement speeds: $\mathrm{S} 1-1.19 \mathrm{~m} \mathrm{~s}^{-1}$; $\mathrm{S} 2-1.44 \mathrm{~m} \mathrm{~s}^{-1} ; \mathrm{S} 3-1.75 \mathrm{~m} \mathrm{~s}^{-1}$; $\mathrm{S} 4-2.05 \mathrm{~m} \mathrm{~s}^{-1}$. 


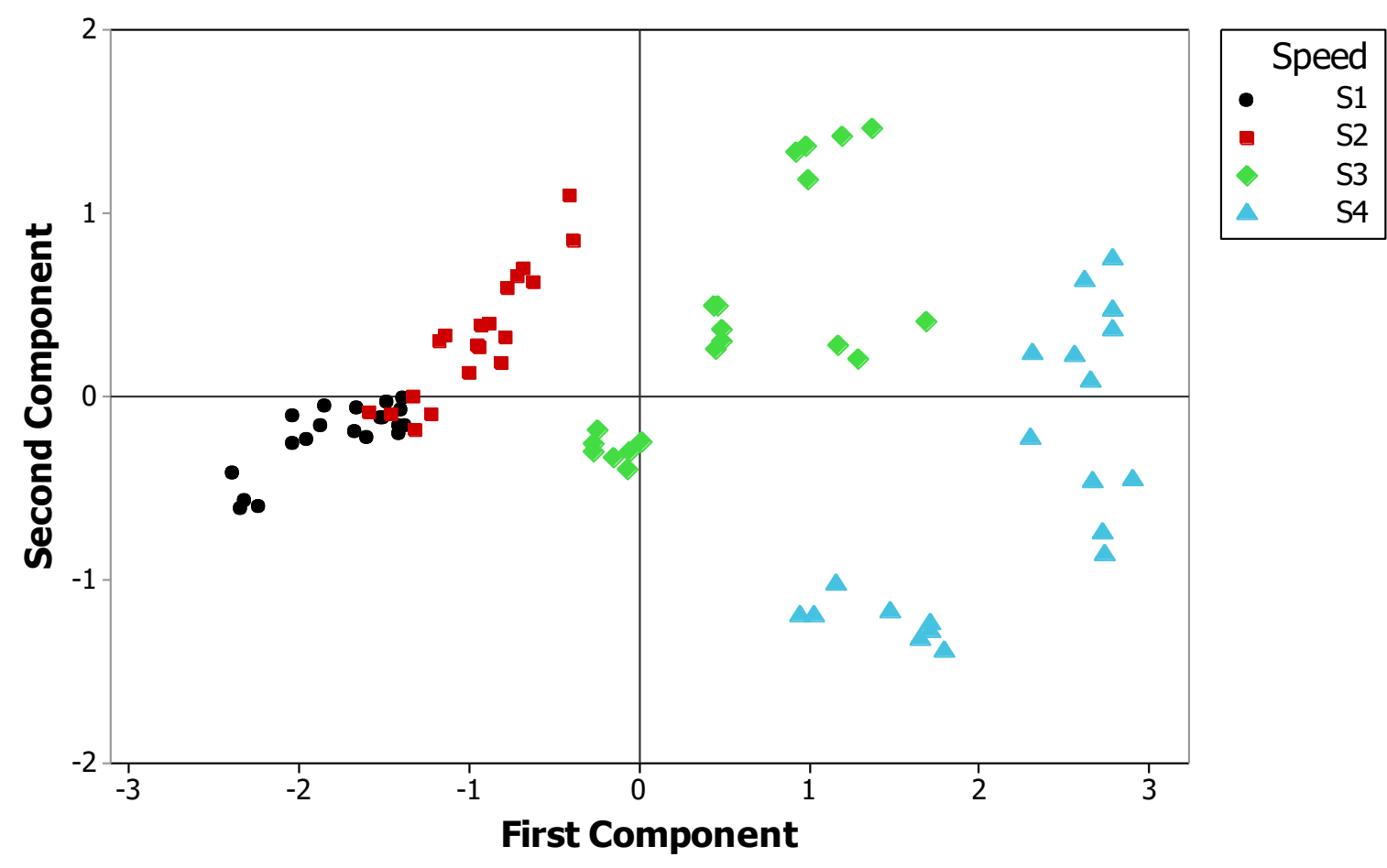

Figura 5 - Dispersion of vibration dose values (VDV) for the different displacement speeds: $\mathrm{S} 1-1.19 \mathrm{~m} \mathrm{~s}^{-1}$; $\mathrm{S} 2-1.44 \mathrm{~m} \mathrm{~s}^{-1} ; \mathrm{S} 3-1.75 \mathrm{~m} \mathrm{~s}^{-1} ; \mathrm{S} 4-2.05 \mathrm{~m} \mathrm{~s}^{-1}$.

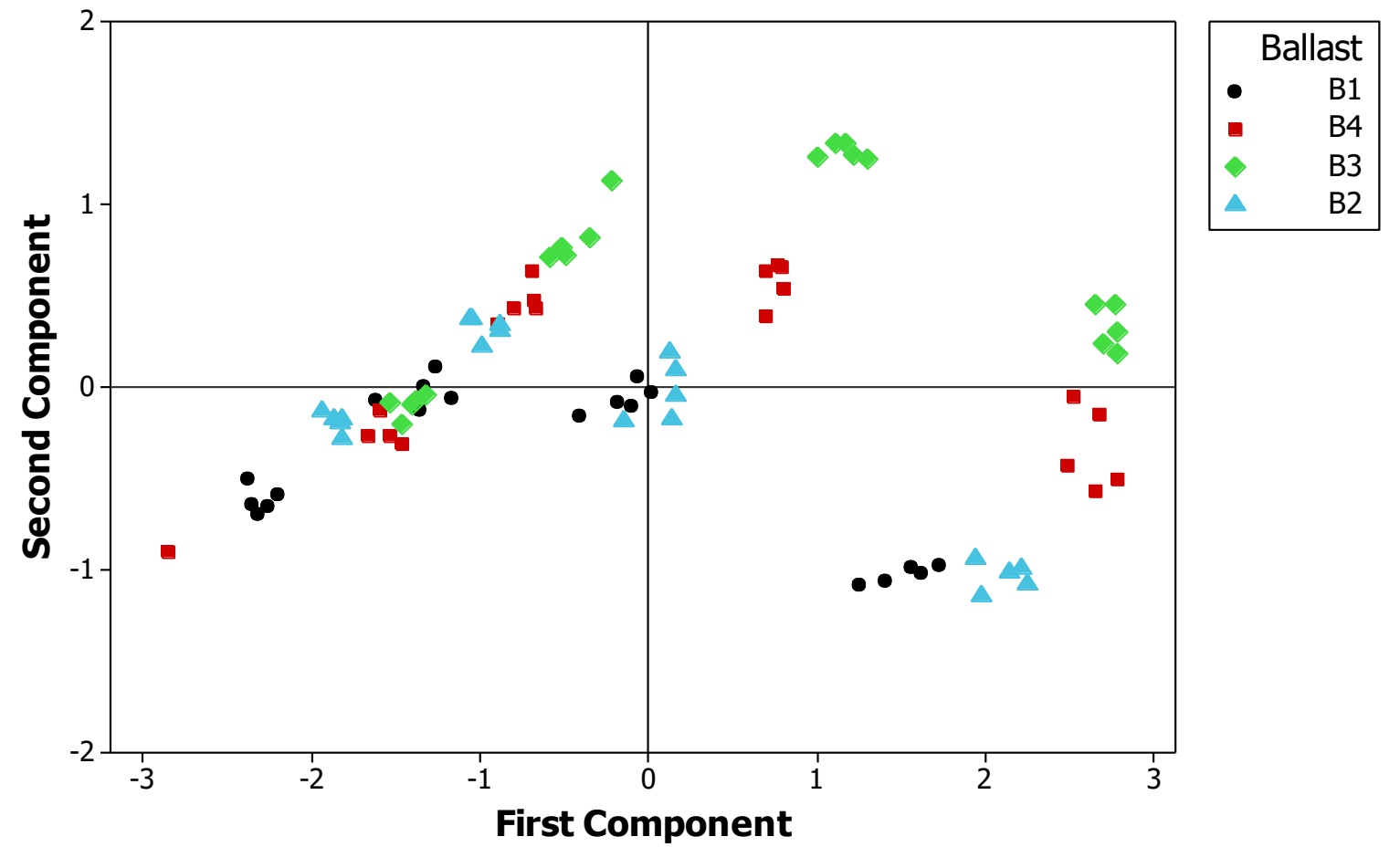

Figura 6 - Dispersion of the mean acceleration values for different ballasts: $\mathrm{B} 1$ - $70 \mathrm{kN}$ - using solid and liquid ballasts; B2 - $54 \mathrm{kN}$ - only solid ballast; B3 - $54 \mathrm{kN}$ - only liquid ballast; B4 - $48 \mathrm{kN}$ - absence of any additional ballast. 


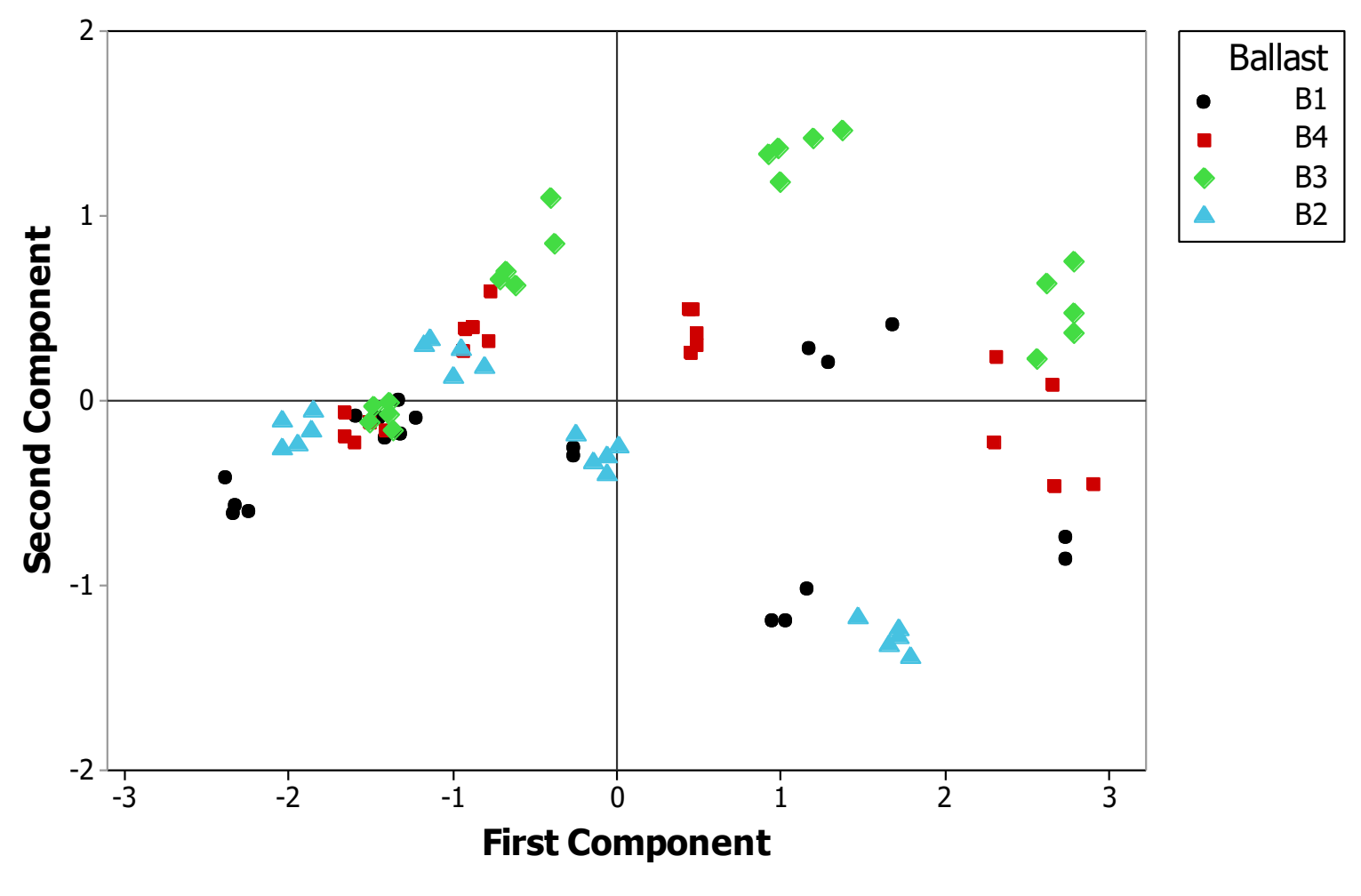

Figura 7 - Dispersion of vibration dose values (VDV) for different ballasts: $\mathrm{B} 1$ - $70 \mathrm{kN}$ - using solid and liquid ballasts; B2 - $54 \mathrm{kN}$ - only solid ballast; B3 - $54 \mathrm{kN}$ - only liquid ballast; B4 - $48 \mathrm{kN}$ - absence of any additional ballast.

The data distribution indicates that the speed also had a great influence on the vibration dose values obtained in the test due to the formation of almost totally distinct groups, with the data on $\mathrm{S} 1$ and $\mathrm{S} 2$ having a similar behavior, while the speeds S3 and S4 are totally different from the others. This may indicate a different interaction between the factors that generate and affect the driving and the distribution of vibrations by the tractor to the operator.

This can be circumvented by the adoption of mechanical components that help stabilize the machine, since, according to Hilton \& Morani (1975), tractor cab suspension systems allow the adoption of considerably higher operating speeds without raising levels of discomfort of the operator, and without compromising safety.

Pinho et al. (2014a) obtained different accelerations between the speeds tested, where the speed of $4.5 \mathrm{~km} \mathrm{~h}^{-1}$ resulted in an increase of $13.5 \%$ in the value of the accelerations in the vertical direction in relation to the speed of $3.5 \mathrm{~km} \mathrm{~h}^{-1}$. Zehsaz et al. (2011) also indicate positive relationships between the increase of the working speed and the vibrations in the operational position.

It can be seen that the values of mean acceleration and VDV for the different ballasts follow a similar behavior among themselves, making it possible to define curves for each type of ballast. From this, it can be observed that a larger weight and the solid ballast act as attenuators of the vibration, since the greater ballast and the use of solid ballast alone generated lower levels of mechanical vibration. This may have occurred due to greater ease of movement with the tractor in a lighter condition and the inertia caused by the movement of water inside the tires when using only this type of ballast. Pinho et al. (2014b) also concluded that the use of all-metal ballast caused the smallest magnitudes of accelerations, regardless of directions, when compared to the other ballasts used in the test.

\section{Conclusions}

The combinations of liquid ballast and absence of ballasts with the highest working speed result in the highest values of mean acceleration.

Reduced speed results in lower vibration dose values.

The acceleration values on the $y$ axis are more responsible for the data distribution behavior than the other accelerations.

The displacement speed of the tractor is more decisive than the ballast. 


\section{Acknowledgements}

To the National Council for Scientific and Technological Development (CNPq), for granting financial support to this research; and to the "ad hoc" rapporteurs of this article, for the important suggestions and corrections.

\section{References}

Balbinot, A (2001) Caracterização dos níveis de vibração em motoristas de ônibus: Um enfoque no conforto e na saúde. Universidade Federal do Rio Grande do Sul (Tese doutorado em Biomecânica).

Brasil. Ministério do Trabalho e Emprego (2014) Atividade e operações insalubres. NR 15 - Anexo 8: Vibrações. Available at < http://trabalho.gov.br/images/Documentos/SST/NR/ NR15/NR15-ANEXO8.pdf > (accessed oct 02 2017).

Cunha JPAR, Duarte MAV, Rodrigues JC (2009) Avaliação dos níveis de vibração e ruído emitidos por um trato $r$ agrícola em preparo de solo. Pesquisa Agropecuária Tropical 39(4):348-355.

Franchini D (2007) Análise do nível de vibrações verticais no assento de um trator agrícola. Universidade Federal de Santa Maria (Dissertação mestrado em Engenharia Agrícola).

Fundacentro (2013) Norma de higiene ocupacional: NHO 09: avaliação da exposição ocupacional a vibrações de corpo inteiro: procedimento técnico. Fundacentro. $63 \mathrm{p}$.

Hilton DJ, Morani P (1975) Experiments in improving tractor operator ride by means of a cab suspension. Journal of Agricultural Enginerring Researh 20(4):433448.

ISO - International Organization For Standardization (1997) 2631-1: Mechanical vibration and shock evaluation of human exposure to wholebody vibration - Part I: general requirements. Geneva, Switzerland: International Standard.

ISO - International Organization For Standardization (2002) 5008: Agricultural wheeled tractors and field machinery - measurement of whole-body vibration of the operator; Geneva, Switzerland.

Koley S, Sharma L, Kaur S (2010) Effects of occupational exposure to whole-body vibration in tractor drivers with low back pain in Punjab. Anthropologist 12(3):183-187.
Lines JA (1987) Ride vibration of agricultural tractors: transfer functions between the ground and tractor body. Journal of Agricultural Enginerring Researh 37:81-91.

Marsili A, Ragni L, Santoro G, Servadio P, Vassalini G (2002) Innovative systems to reduce vibrations on agricultural tractors: comparative analysis of acceleration transmitted through the driving seat. Biosystems Engineering. $\quad 81(1): 35 \quad$ - 47. DOI:10.1006/bioe.2001.0003. ISSN: 1537-5110.

Mehta CR, Shyam M, Verma RN (2000) Ride vibration on tractor-implement system. Applied ergonomics 31(3):323-328. DOI: 10.1016/S0003-6870(99)00050-2.

Nguyen VN, Inaba S (2011) Effects of tire inflation pressure and tractor velocity on dynamic wheel load and rear axle vibrations. Journal of Terramechanics, 48(1):3-16.

Pinho MS, Schlosser JF, Frantz UG, Farias MS, Uhry D, Ribas RL (2014a) Acelerações eficazes na interface assento-operador de um trator. Ciência Rural 44(10):1797-1803. DOI: 10.1590/0103$8478 \mathrm{cr} 20121103$.

Pinho MS, Schlosser JF, Frantz UG, Rodrigues FA, Ferrer PS (2014b) Efetividade de um coxim de cabina do trator agrícola na atenuação das vibrações. Revista Ciência Agronômica 45(3):461-468.

Santos LN, Fernandes HC, Souza AP, Furtado Júnior MR, Silva RMF (2014) Avaliação dos níveis de ruído e vibração de um conjunto trator-pulverizador, em função da velocidade de trabalho. Engenharia na Agricultura 22(2):112-118. DOI: $10.13083 / 1414-$ 3984.v22n02a02.

Scarlett AJ, Price JS, Stayner RM (2007) Whole-body vibration: Evaluation of emission and exposure levels arising from agricultural tractors. Journal of Terramechanics 44(1):65-73.

Silva CB, Volpato CES, Andrade LAB, Barbosa JA (2011) Avaliação ergonômica de uma colhedora de cana-de-açúcar. Ciência e Agrotecnologia 35(1):179185. DOI: $10.1590 /$ S1413-7054201100 0100023.

Zehsaz M, Sadeghi MH, Ettefagh MM, Shams F (2011) Tractor cabin's passive suspension parameters optimization via experimental and numerical methods. Journal of Terramechanics 48(6):439-450. 